\title{
SELF-DEVELOPMENT THROUGH SELF-OBSERVATION FOR TEACHER OF ENGLISH AS A FOREIGN LANGUAGE
}

\author{
Susi Eka Lestari \\ Faculty of Literature \\ Islamic University of North Sumatra, Medan \\ lestarie20@yahoo.com
}

\begin{abstract}
This research is a literature research discussing self-development through selfobservation for teacher of English as foreign language. Karaaslan (2003: 3033) said that self-development is very important if we want to be professional teachers. Richards (2007: 12) said that observation is done by visiting a class to observe different aspects of teaching. This research is aimed to find a new paradigm for teachers of English as foreign language. Hopefully, the finding of this research will give significant contribution to those whose profession is English teacher. There is a new paradigm found by this research. It is cycling process of self-development through selfobservation.
\end{abstract}

Key words : Teacher, Development, Observation, Cycling

\section{INTRODUCTION}

Teachers of English as a foreign language need to be able to handle different roles. It is said so because teaching a foreign language is different from those who teach in native language. It is because the participants or the students know little even nothing about English language. Therefore, there must be changes in teaching performances by the teachers to find the proper way in teaching a foreign language. For this, they need to be competent speakers of English. On the other hand, they are under pressure to make the learning process real for their students, to help learners authenticate language so that they can make it their own in various contexts of use, including those of the classroom specifically designed to induce such learning. In other words, teachers should be competent pedagogues (instructors) (Seidlhofer, Barbara. 1996: 68-69). Difficulties may arise when teachers have to reach their teaching achievement. For this, there must be any efforts by the teachers to make development in their teaching performances.

It is a matter of self-development in teaching. As it is said by Karaaslan (2003: 30-33) that self-development is very important if we want to be professional teachers. He also said that selfdevelopment can be achieved by selfobservation. He emphasized that selfobservation is better obtained by using video as an observational tool by teachers. In other words, teachers should make a record of their teaching performance in their classes because teachers have a chance to find out about their own personalities in their teaching performance by using video recording. Therefore, teachers find opportunities to observe their students more closely and notice something they were not aware of in their teaching performance. Then, they can evaluate their own ways of speaking, explaining, and other elements in their teaching performance. Furthermore, teachers who make such an observation will increase their awareness and be more systematically in teaching. Thus finally, they will be a professional development in teachers' teaching performance in teaching foreign language.

English is regarded foreign language in many countries including Indonesia. However, English is taught in those countries in which English is a foreign language. Teaching English as a foreign language is a little bit problematic in Indonesia. It is the problem of the suitable ways in teaching. Therefore, there are many teaching method proposed to English teachers. Still, there are many obstacles found by teachers. Teacher feels that they are not at their target of 
teaching after finishing the class. This study tries to present a solution or an alternative for English teachers to improve their teaching performance to achieve their teaching achievement. This is experienced by many teachers of English as a foreign language. Therefore, the writer is eager to make such a kind of research.

It is hopefully that this research will give benefit to those who are teaching English as a foreign language. Although, there are many researches focused their subject matter on this topic, at least this research will add their references to make any improvement in their teaching performance.

English as a foreign language will be easier to be mastered if it is acquired not taught. In other words, younger beginners will be able to use foreign language easily than the older or adult beginners. It means that it is the critical period of the learner that is proper time for them to learn foreign language. Critical period is the period where learners will acquire foreign language automatically from mere exposure, while older learners have to make conscious and labored efforts (hyltenstam \& Abrahamssaon. 2000: 152). Therefore, teachers of English as a foreign language whose students are adult need to develop themselves in their teaching performances.

\section{REVIEW OF RELATED LITERATURE}

\section{Self - Development}

There are several factors that affect teachers' self-development. According to Gebhard (2014: 8-10), the factors are as follows:

1. There is no doubt that development takes time. It takes time to observe interaction in his or her classrooms and to visit other teachers' classes as well as to write in a journal and to talk to other about teaching.

2. Development requires an ongoing commitment. It means that most experienced teachers can learn new things about teaching, and development is enhanced when the teacher makes a commitment to ongoing development.
3. Development is enhanced through problem solving. When teachers recognize problems and make at solving them, they can discover new ways to teach and discover more about their role a $\mathrm{s}$ a teacher.

4. Development is also enhanced through exploration for exploration's sake. Teachers can, indeed, discover much by exploring simply to explore, not just to solve a problem.

5. Development is enhanced by paying attention to and reviewing the basic of EFL/ESL teaching.

6. Development is enhanced by searching on opportunities to develop. Teachers search information about teaching by reading, writing, listening, talking, and joining workshops or seminars on teaching.

7. Self-development of teaching beliefs and practices requires the cooperation of others. It takes others who are willing to observe us, listen to us, talk with us about teaching. Teachers need administrators, students, other teachers, and friends to help us succeed with our development.

This idea is supported by Richards (2007: 3-4) who proposed the assumptions about the nature of teacher development. There are five assumptions as described below:

1. An informed teacher has an extensive knowledge base about teaching. Teaching is a complex, multidimensional activity. The teacher who has a more extensive knowledge and deeper awareness about different dimensions and components of teaching is better prepared to make appropriate judgment and decision in teaching.

2. Much can be learned about teaching through self-inquiry. Teachers collect information about their teaching either individually or through collaborating with colleague, make decision about their teaching, decide it initiatives need to be taken, and select strategies to carry them out. 
3. Much of what happens in teaching is unknown to the teacher. Teachers are often unaware of the kind of teaching they do or how they handle many of the moment-to-moment decision that arises. This unawareness could be solved by collecting and examining data on many dimensions of teaching.

4. Experience is insufficient as a basis for development. Many aspects of teaching occur day in and day out, and teachers develop routines and strategies for handling these recurring dimensions of teaching. However, many research suggest that, for many experienced teachers, many classroom routines and strategies are applied almost automatically and do not involve a great deal of conscious thought or reflection. Experience is the starting point for teacher development, but in order to make experience play a productive role, it is necessary to examine such experience systematically.

5. Critical reflection can trigger a deeper understanding of teaching. It involves examining teaching experiences as a basis for evaluation and decision making and as a source for change.

The above assumption reflect the fact that I teachers are actively involved in reflecting on what is happening in their own classroom, they are in a position to discover whether there is a gap between what they teach and what their learners learn.

Lipka (1999: 3) has different idea about self-development. He said that selfdevelopment could be effectively utilized as a 'gate-keeping' function. It means that before being a teacher, someone's should own critical criteria for teacher. It includes 'personal' aspects such as one's level of maturity, self-esteem, personal responsibility, and overall emotional and psychological fitness. It is summarized in his book that teachers with the clearest and most positive sense of self are in the best position to facilitate the growth, development, and of the million young people who greet them each morning at the schoolhouse door. This idea implies that before being a teacher, one should be mature enough in some personal aspects to called that he is good in his self-development.

\section{Self - Observation}

Richards (2007: 12) said that observation is done by visiting a class to observe different aspects of teaching. There are two kinds of observations. They are:

1. Observation by students or teachers of a cooperating teacher's class.

2. Peer observation. It is conducted by one teacher who observes a colleague's class.

As teachers, we can explore through a process of describing, analyzing, and reflecting on our teaching. The process observation is done in some cycle process (Gebhard. 2014: 18). They are as follows:

1. Collecting descriptive samples of our teaching in the classroom that can be analyzed. The samples are obtained by recording what is going on in the classroom. Then we make the transcript of the recorded samples.

2. Considering how the same lesson could be taught differently and drawing up a new teaching plan.

3. Implementing the new teaching plan.

4. Doing the same three steps as the cycling process.

In his other book, Richard (1997: 9) said that an alternative approach to the study of teaching and to the development of goals for teacher preparation program is the examination of the total context of classroom teaching and learning in an attempt to understand how the interactions between and among teachers, learners, and classroom tasks affect learning. According to him this can be called as a holistic approach because it focuses on the nature and significance of classroom events and involves both low-interference and high-interference categories.

Self-observation is absolutely fulfilled by the teachers themselves. Teachers should observe their own classes to find any improvement in their teaching 
performance for a better achievement. In Burn (2010: 7-8), it is said that there are four stages to create a cycle observation. Still, he said that it is the model used in Action Research. The first cycle may becomes a continuing, iterative, spiral of cycle which recur until the action researcher has achieved a satisfactory outcome and feels it is time to stop. The followings are the phases in Action Research:

1. Planning

In this phase you identify a problem or issue and develop a plan of action in order to bring about improvement in a specific area of the research context.

\section{Action}

The plan is a carefully considered one which involves some deliberate intervention into your teaching situation that you put into action over an agreed period of time. The interventions are critically informed as you question your assumptions about the current situation and plan new and alternative ways of doing things.

\section{Observation}

This phase involves you in observing systematically the effects of the action and documenting the context, actions and opinions of those involved. It is a data collection phase where you use 'open-eyed' and 'openminded' tools to collect information about what is happening.

\section{Reflection}

At this point, you reflect on, evaluate, and describe the effects of the action in order to make sense of what has happened and to understand the issues you have explored more clearly. You may decide to do further cycles of action research to improve the situation.

Dealing with this self-observation, Alatis et.al (1983:288) said that teachers need to monitor their own or colleagues' classrooms. It means that it is necessary for teachers to monitor themselves in their teaching performances. It is absolutely needed to make improvement in their teaching performance. In other words, it has relationship to self-development of teachers in their teaching.

Samaras (2011: 5-11) has different term that the writer think it has the same purpose in its meaning with selfobservation. He called it 'self-study'. This self-study consists of some criterion as follows:

1. Self-study is a personal situated inquiry. It draws directly from teachers' personal experiences, which is situated within their classroom.

2. Self-study is critical collaborative inquiry. It includes personal and interpersonal with learning, thinking, and knowing arising through collaboration and the appropriating of feedback from others.

3. Self-study is to improve learning. It means that self-study will improve teachers' work as professionals, especially, in making decision and reforming their teaching performances.

4. Self-study is a transparent and systematic. It means that it is done with an open, honest, and clear description of the spiral of questioning, framing, revisiting of the data, and reframing a researcher's interpretations.

5. Self-study is knowledge generation and presentation. It means that it will emphasize teachers' knowledge or skill in their teaching performances.

The idea about self-observation proposed by different experts above seems to have similar core point. Therefore, they are in mutual position. There are some criterion of one theory are not found in other and vice versa.

\section{DISCUSSION}

This research is aimed to make collaboration among different theories about self-development and selfobservation in a systematic feature. As stated above, the theories adopted in this research has mutual relationship, therefore, in this sub chapter the writer would like to put them in a systematic 
drawn as clear as possible for teacher to understand then to apply. Hopefully, the readers of this research will catch easily the message or the steps and the actions that they should have and apply from the chart. However, the writer also makes the description of the chart in a narration. It is to clarify the points poured in the chart.

The following is figure 1 (Cycling Process of Self-Development through Self-Observation):

Figure 1: Cycling Process of Self-Development through Self-Observation

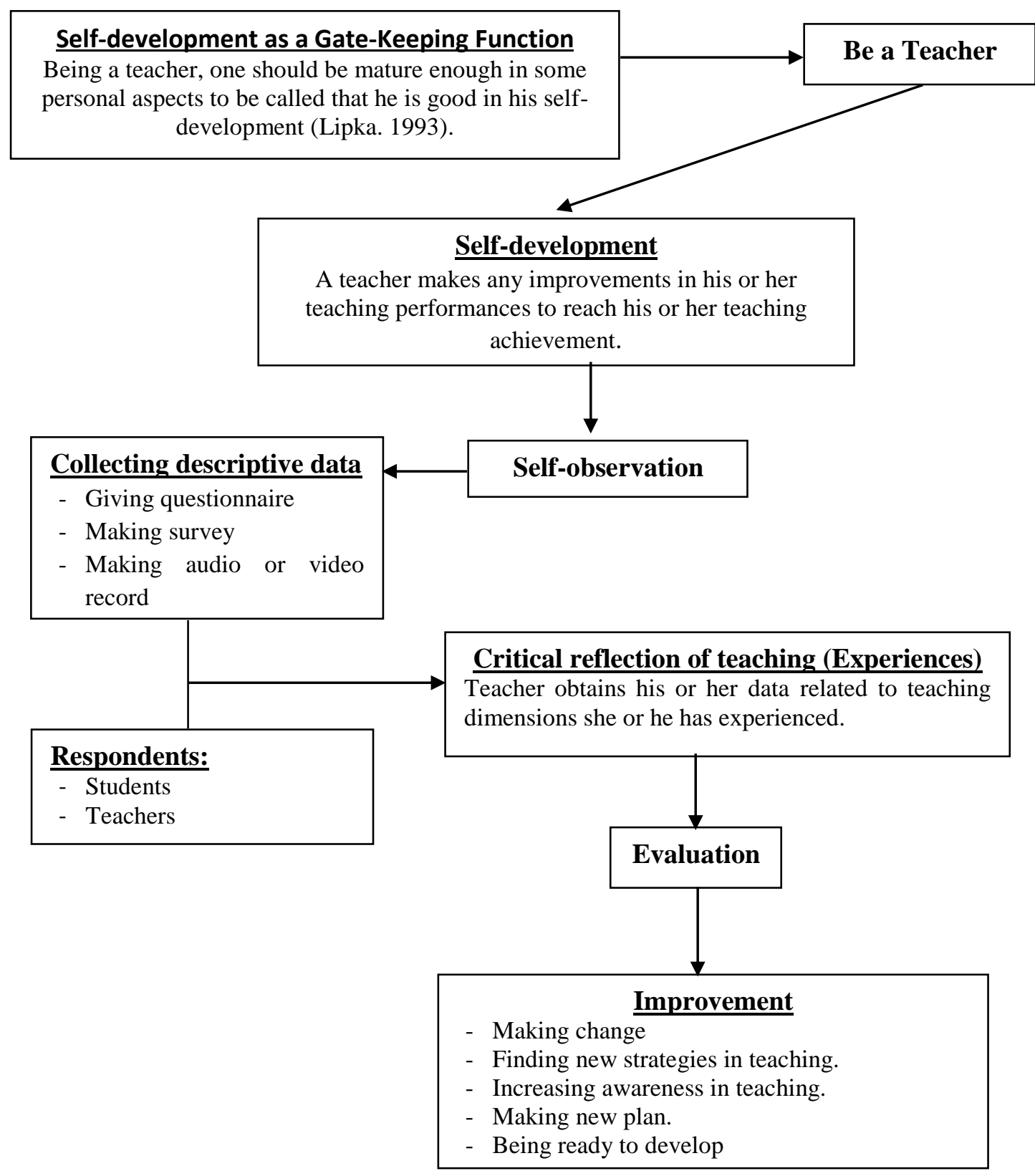




\section{Description}

Lipka's understanding about selfdevelopment is that teachers should be mature enough in his or her personalities. Thus, their decision to be a teacher is base on well-thought consideration. That is why he calls that self-development is as 'gate-keeping' function. In other words, it is the starting point for them to make a choice to be a teacher. It is called personal maturity because age of someone does not guarantee that someone is mature enough to an educator or teacher. A teacher should be mature personally because teacher's duty only can be conducted by a person who are ready to face any challenges and should be able to find the solution for the challenges.

After being a teacher, someone should think his professionalism. It means that she should be at his best in his teaching performances. Therefore, a teacher should be aware of his selfdevelopment. To develop is something that should be considered well by teachers because by making any development they will be better and better in their update teaching performances.

Self-development as figured in the chart is through self-observation. It is a way for teachers to obtain data to observe their teaching performances. They collect the data by giving questionnaire, making survey, and making audio or video record. The instruments of collecting the data are given to their students and their colleagues. The data reflects their experiences in their teaching performances dealing with the dimensions in teaching. Then, they make any evaluation from the data collected because the data will show them their weakness or their improperness. They might be in the form of the way they explain the materials, they way they make note on the board, they way they give questions, they way they respond their students' question, the way they read the situation before starting their teaching, and et cetera. It is called selfobservation because teachers are observing the data containing their own descriptive data. It is done to make any development in their teaching performances.

Teachers who have found their problems from their descriptive data, then they are ready to make any improvement.
The improvement is fulfilled by some ways such as, finding new strategies, making new plan by keeping in mind that there must be changes in their new plan, and increasing awareness in their teaching performances. Their new strategies are made in accordance to their findings in their descriptive data. In other words, the effort that they take must offer solutions to their problems, thus they can develop and can be a real professional as a teacher.

The new paradigm in figure 1 is called cycling process. It means that this process might be repeated until teachers get the final findings and solution. In other words, they have no more problems as their challenge to be solved. The next step, teachers might expose them in a form of research to be known by other colleagues.

\section{FINDING}

This research finds that selfdevelopment can be realized by selfobservation as seen in figure 1. One's development will only be reached by repeated the same steps until he think it is the time to stop. However, selfdevelopment can also be reached by other ways such as through self-reflection, self-study, and others that might be elaborated in other research.

\section{REFERENCES}

Alatis, James E, et.al. 1983. Applied Linguistics and the Preparation of Second Language Teachers: Toward a Rationale. Washington D.J: Georgetown University Press.

Burn, Anne. 2010. Doing Action Research in English Language Teaching: A Guide for Practitioners. New York: Routledge.

Gebhard, Jerry G. 2014. Teaching English as a Foreign or Second Language: A Self - Development and Methodology Guide. Michigan: The University of Michigan Press 
Hyltenstam, K. and Abrhamsson, N. 2000.

Who can Become Native-Like in a Second Language? All, Some or None? On theMaturational Contraints Controversy in Second Language Acquisition. In Studia Linguistica 54(2), 150-166

Karaaslan, A. Dilsad. 2003. Teachers'Perceptions of SelfInitiated Professional Development: A Case Study on Baskent University English Language Teacher. Baskent: The Department of Educational Sciences

Richard, Jack C. 1997. Second Language Teacher Education. Cambridge: Cambridge University Press.

Richards, Jack C. 2007. Reflective Teaching in Second Language Classroom. Cambridge: Cambridge University Press.

Samaras, Anastasia. 2011. Self-Study Teacher Research: Improving Your Practice Through Collaborative Inquiry. California: SAGE Publication Inc.

Seidlhofer, Barbara. 1996. "It is an Undulating Feeling..." The Importance of Being a Non-Native Teacher of English. In Vieanna English Working Papers Vo. 5 (No.1-2). Wien: VIEWS 